v.9, n. 1

Vitória-ES, Jan-Mar 2012

p. 103-124 ISSN 1808-2386 DOI: http://dx.doi.org/10.15728/bbr.2012.9.1.5

\title{
The Influence of foreign expressions in the process of building agribusiness brands in Brazil
}

\author{
Rodrigo de Carvalho Leite ${ }^{t}$ \\ Rio Grande Federal University- FURG \\ César Augustus Winck $\Omega$ \\ West Santa Catarina University - UNOESC \\ Valdecir José Zonin ${ }^{¥}$ \\ Rio Grande do Sul Federal University - UFRGS
}

\begin{abstract}
Nowadays companies are devoting increasing resources to create brands because of the importance of these signs in generating financial returns. In Brazil there is a growing influence of foreign expressions in the brands created by local firms, making this phenomenon an interesting target of research. The central objective of this article is to analyze how foreignisms influence the process of building brands by three Brazilian agribusinesses, called A, B and C, located in the state of Rio Grande do Sul. For this purpose, we carried out an exploratory study, based on data gathered from interviews with executives from key areas of the respondent firms as well as secondary sources. Through content analysis, we verified that the companies surveyed try to plan their marketing actions with the aim of making their marketing mix more effective and efficient, in partnership with advertising agencies and consultants. On the particular matter of the use of foreign expressions, these are used largely because of the internationalization of firms in the agribusiness sector. In this respect, it is important to adjust the various meanings, beliefs, attitudes, motivations, values and perceptions of consumers through the construction of brands in harmony with foreign influences, with the aim of reducing ineffective results and negative consequences.
\end{abstract}

Keywords: Management; foreignisms; brands; communication; consumers.

Received on 10/28/2010; reviewed on 04/13/2011; accepted on 08/01/2011; avaialable in 05/03/2012

Corresponding author*

${ }^{\dagger} \mathrm{PhD}$ Student in Agribusiness by CEPAN, PPG Agribusiness, Federal University of Rio Grande do Sul UFRGS

Address: Rua Irmã Ambrósio, 412 Bairro Agronomia - Porto Alegre RS - Brazil.

E-mail: rodrigoleite.ind@ hotmail.com Telephone: (51) 9984.56733

\author{
${ }^{\Omega} \mathrm{PhD}$ Student in Agribusiness by \\ CEPAN / UFRGS and a Master of \\ Veterinary Science at Science Center \\ Agroveterinárias State University of \\ Santa Catarina - UDESC \\ Address: Rua Getúlio Vargas, 2125 \\ Joaçaba - SC - Brazil. \\ E-mail: cesar.cepan@gmail.com \\ Telephone: (49) 3247-0661
}

\author{
${ }^{¥} \mathrm{PhD}$ Student in Agribusiness by \\ CEPAN, PPG Agribusiness, Federal \\ University of Rio Grande do Sul - \\ UFRGS \\ Address: Avenida Getúlio Vargas, 1181 \\ apto. 303, Bairro Menino Deus, Porto \\ Alegre - RS - Brazil. \\ E-mail: valdecirzonin@ erra.com.br \\ Telephone: (54) 99746853
}

Nota do Editor: Esse artigo foi aceito por Antonio Lopo Martinez. (cc) EY-NC-SA

Esta obra está licenciada sob a Licença Creative Commons - Atribuição-Uso não-comercial-Compartilhamento pela mesma licença 3.0 Unported License 1 


\section{INTRODUCTION}

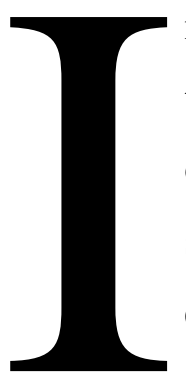

$\mathrm{n}$ the contemporary economy, the fast pace with which firms can match the technological advances of competitors means that multiple manufacturers can offer products with the same general technical specifications and similar quality standards, eliminating significant physical differences. This context leads to more emphasis on developing brands as an element of differentiation. A brand thus not only represents a real product, it encompasses a set of values and tangible and intangible attributes, differentiating the products of one firm from similar ones made by other firms.

As the supply of products and services increases, so do the options from which consumers can choose, and when new products compete in highly specific market segments, other factors start to have a more important role in brand selection.

The world is in a constant process of change, one of the main ones being the emergence of a new type of citizen - more informed, critical and aware, with greater participation in society. The influence of brands to companies ${ }^{\text {ee }}$ success is increasingly unquestionable in light of the power shown by brands, with successful ones able to create positive scenarios that assure products good positions in the consumer market that can withstand the advances of competitors for long periods (Pinho, 1996). This battle of brands will be won by the firm that conquers the greatest share of preferences among consumers (Keller, 1998).

The management of a brand involves the creation and maintenance of an organized set of functional characteristics and symbolic aspects, in an effort to establish a competitive advantage for the firm. The way consumers react to a brand can be divided into four basic categories: brand name recall, perceived quality, positive associations and fidelity. All

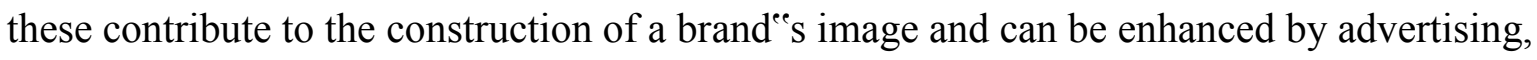
which stands out from the various means of communication both for the high level of control over messages and the ability to convince consumers in general (Pinho, 1996).

In many companies a steadily growing influence can be noted of foreign expressions, from French, Spanish and mainly English (as well as aspects of foreign symbols, flag colors and other typologies) in the construction of regional brands. Indeed, some complain it is becoming common for citizens to feel like foreigners in their own country. For some, the influence of English, a constant presence in Brazilian society, is a threat that generates discomfort and indignation at the erosion of our good and valuable 
Portuguese (Pinho, 1996). Therefore, it is important to properly manage the construction and consolidation of brands with respect to the pros and cons of foreign influences.

The aim of this study is to analyze the way foreignisms influence the process of building brands in three firms in the agribusiness sector. We classified the firms generically as $\mathrm{A}, \mathrm{B}$ and $\mathrm{C}$ to preserve their identity and strategic information.

\section{LITERATURE REVIEW}

\subsection{Foreignisms}

The marketing environment has been undergoing various transformations against a backdrop of dynamic globalization, affecting companies of all sizes. In this context, firms, societies and the cultural outlines of different countries are become globalized at a frantic pace (Kotler, 1998).

Companies are directly interconnected with the culture and society in which they act. The fixation of many Brazilians on foreign influences cannot help but have a significant influence on companies. Therefore, the cachet attached to the foreign, the imported, can be perceived to a greater or lesser extent by Brazilian firms.

Foreign influence is reason for discussion in many areas. For example, there is a bill in Congress "to promote, protect and defend the use of the Portuguese language." This bill demonstrates that its author questions the influx of foreign influence by means of terms and expressions from other languages, increasingly employed in the country, especially words of English origin. People who support such efforts, for example, can be assumed to frown on the expression "Personal Banking" that appears on the automatic teller machines of the state-controlled Banco do Brasil throughout the country (Bagno, 2000).

Portuguese words fall into disuse as they are replaced by foreign imports. Nowhere is this greater than in informatics, where English terms involving both computer equipment and programs and all the associated technology are commonly applied. A huge array of imported terms are becoming perfectly natural today to Brazilians of all social classes, as the gradual process of foreignism inculcates these terms into our daily vocabulary (Bagno, 2000).

Foreign influences are also strong in business, because the access to different cultures is increasingly present in daily life, where consumers the world over are subject to the influence of foreign images. The speed with which these new identities and images will 
be adopted depends on the attitude of each consumer in relation to these influences (Simonson, 1997).

Chart 1 shows that when consumers have high awareness and acceptance of foreignisms in a brand, this allows standardization, irrespective of the differences that may exist between the cultures, as shown in the first quadrant (Q1). The second (Q2) represents the situation of high awareness but low acceptance. This high awareness alone does not make the firm certain that the foreign brand will be successful, requiring efforts to enhance its image. The third quadrant (Q3) represents low awareness and high acceptance, which requires greater efforts to instruct the public about the foreign country and brand. And lastly, the fourth quadrant (Q4) reflects low awareness and low acceptance by consumers, requiring the company to analyze its objectives and revise its processes of instructing the public and enhancing the brand ${ }^{\text {ees }}$ image.

\begin{tabular}{|l|l|c|c|c|c|}
\cline { 3 - 5 } \multicolumn{2}{c|}{} & \multicolumn{3}{c|}{ Acceptance } \\
\cline { 2 - 6 } Awareness & High & Q1 & Standardization & Q2 & Enhancement \\
\cline { 2 - 6 } & Low & Q3 & Instruction & Q4 & $\begin{array}{c}\text { Instruction and } \\
\text { enhancement of the } \\
\text { image }\end{array}$ \\
\hline
\end{tabular}

Chart 1 - Awareness and acceptance of consumers

Source: (Simonson, 1997)

In Brazil there is a growing trend to give foreign names to children as well as commercial and service establishments. For children, names like João, Manuel and Maria are giving way especially to English ones like Johnny, Kennedy and Marilyn (Carvalho, 1989) For this reason, the author states that Brazilians "e lifestyle and mother tongue are becoming infused with "made in the USA" elements, reflecting the predominance of English loan words and names. In using, for example, the terms „leasinge, „royalties ${ }^{\text {ee }}$ and „managemente, Brazilian citizens appear to more in touch with political and economic power. The imitation bred by admiration can also be seen in the cinema, music, fashion and television, generating indiscriminate use of English terms, which winds up causing anarchy in Portuguese spelling conventions (Carvalho, 1989).

In turn, Staub (1983) points out that the unnecessary use of a foreign word impairs 
the meaning of the word in Portuguese, to the point of even hampering communication between people, with foreign words being used by people who are unaware of the structure of the language from which the foreign word comes.

The International Organization for Standardization (ISO), with headquarters in Geneva, has 150 committees for the study of terminologies. Its Brazilian member, the Brazilian Association of Technical Standards (ABNT), has not been very interested in this effort, due to the fact it does not work together with similar associations in other Portuguese-speaking countries. Some countries have taken a more defensive legislative stance (Staub, 1983). Among the international institutions seeking to preserve cultural identity and heritage is the União Latina (in Portuguese, or Union Latine in French, Unió Llatina in Catalan, Unión Latina in Spanish, Unione Latine in Italian or Uniune a Latinã in Romanian), with headquarters in Paris, which groups 22 countries speaking Romance languages, among them Brazil. The institution es purpose is to preserve the heritage and identity of Latin countries by means of language teaching and organization of terminology. In reality, the main aim is to deter the steady advance of the English language by preserving the native languages (Staub, 1983).

\subsection{Brands in the cultural and market environment}

Brands or trademarks have exited for centuries. The use of trademarks, according to Keller (1998), can be traced back to the marks placed on forged metal and fired ceramic pieces that were sold at times in different places than where they were fabricated. These marks were perceived as indications of quality by consumers. Starting in the eleventh century, individual marks came to be obligatory and acquired a more commercial sense. Commercial transactions started to be carried out far from the production center, without a direct relationship between the producer and buyer. Thus, the mark was the element that established a connection between the manufacturer and the consumer who lived far from the place of fabrication. By means of the trademark, the consumer had a way of assuring the quality of the product and could complain when it did not have the proper qualities (Keller, 1998).

Brands aggregate other dimensions to a product, to differentiate it from others created by competitors to satisfy the same need. These differences can be rational and tangible or merely symbolic, emotional and intangible. What distinguishes a branded product from its unbranded commodity counterpart is the sum of consumers ${ }^{e}$ perceptions 
and feelings about the productes attributes and how they perform, about the brand name and what it stands for and the about the company associated with the brand (Keller, 1998).

Attributes are descriptive aspects that characterize a product. They may or may not be associated with the factors necessary for its performance, such as information on price, image or means of use and packaging. The image attributes are formed by the experience of consumers from contact with the brand, word-of-mouth disclosure and personality attributes such as a youthful or active lifestyle, that form a tie between the brand and the product (Tavares, 1998). A brand can also express different personalities in different contexts, making it necessary to understand the contexts in which the branded product is used. This analysis is of basic importance for firms seeking to establish a competitive advantage based on personality, to verify precisely what people think in their respect (Tavares, 1998).

Because personality is an efficient selling tool, the brand ${ }^{\text {ee }}$ personality should be desirable and sufficiently important to the people who use the product. People have to feel better for having an association with the brand, for instance envisioning themselves as having enhanced social status from driving a Lexus, feeling younger when drinking a Pepsi, more sophisticated when using Chanel perfume or more relaxed when drinking a Miller Lite. A personality that does not meet its aim will not function (AAKER, 1998).

According to Tavares (1998), a brand ${ }^{\text {ee }}$ s image can be seen as the set of unique characteristics that distinguish one brand from others. It results from the marketing activities responsible for the perception of the brand formed and held in the consumer"s memory. For Keller (1998), a brand ${ }^{\text {ee }}$ s image is the set of associations linked to the brand that consumers preserve in their memory, resulting from a set of associations, beliefs, perceptions and expectations.

The products and services sold in the market play a role beyond the commercial utilitarian one, by carrying and communicating a cultural meaning, which is in constant change and is located in three places: the culturally constituted world, the consumer good and the individual consumer. Culture can be defined as a set of ideas and activities by means of which people build their understanding of the world, while the notion of consumption includes the processes of creation, purchase and use of the products and services offered (McCracken, 2003).

The value of brands is huge and growing, as revealed by the commercial transactions involving huge sums. The high value of brands calls for careful attention in 
marketing them. But in recent years changes have been occurring that hamper the usual marketing practices, besides requiring greater efforts by experts and brand managers in response to the increased competitiveness among firms due to the constant arrival of new brands and products in the market. Added to this situation is the fact that in some cases a brand can identify various different related products, such as Coca-Cola, where consumers can find its original version along with a diet version, caffeine-free version and version with cherry flavoring (Keller, 1998).

\subsection{Consumers' Brand Perception}

The basic communication model, as shown in Figure 1, which occurs in situations ranging from interpersonal discussion between friends all the way to mass communication transmitted by satellite, is based on the idea of stimulus and response. It can be identified by means of five fundamental elements: a sender, receiver, message, feedback circuit (the ways the source knows the receiver received the message) and noise, the base for the relationship between the source and the receiver (Schultz \& Barnes, 2001).

Common experiences occur in the shaded region and constitute the communication between the sender and receiver. This field is very important in building brands because it permits the company to discover what the marketing personnel and consumers have in common, what consumers think of the products or services and how these correspond to the desires and needs of consumers.

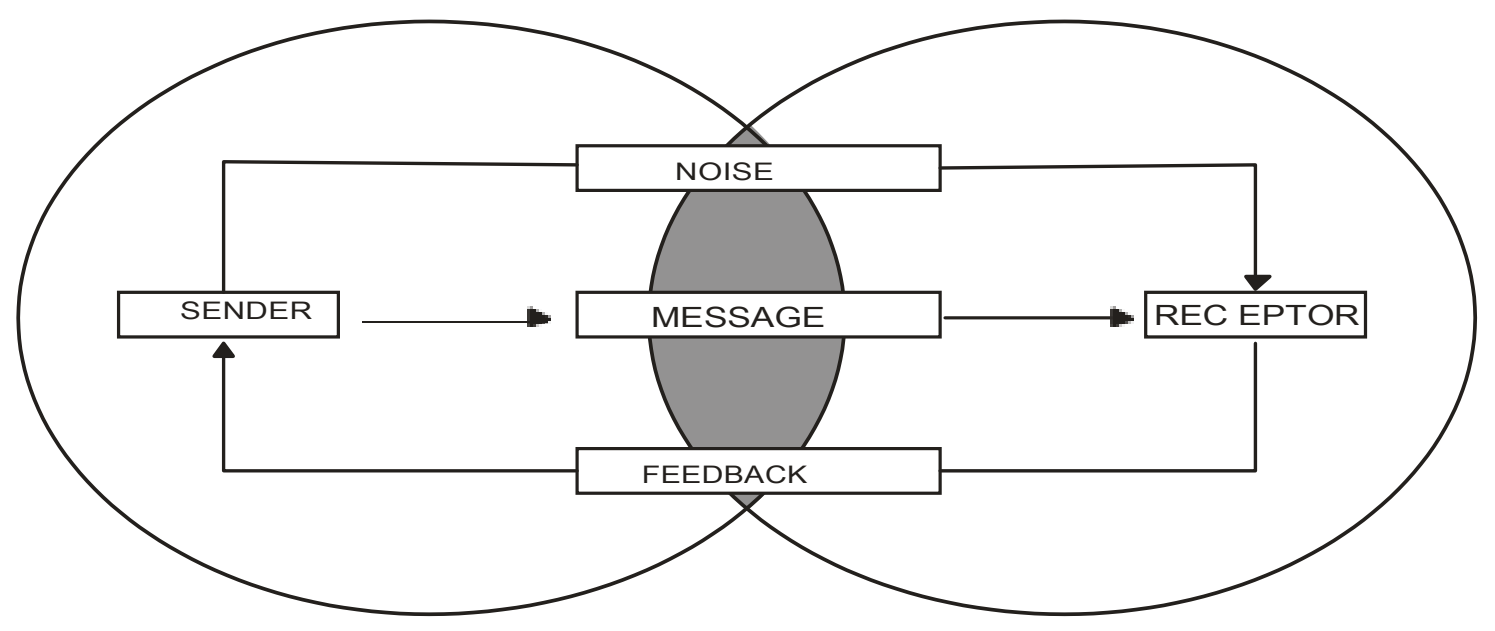

CAMPO DA EXPERIÊNCI A

Figure 1 - Process and effects of communication Source: Schultz\& Barnes (2001, p. 57)

According to Aaker (1998), the first evaluations of how brands are perceived and known by consumers in Brazil started in the 1960s. Brand knowledge or awareness is 
defined as the ability of consumers to recognize or remember that a brand belongs to a certain category of product. This ability ranges from a vague feeling that the brand is known to a belief that it is the only acceptable one in a determined product class. Brand awareness can thus be represented by different levels, as depicted in Figure 2.

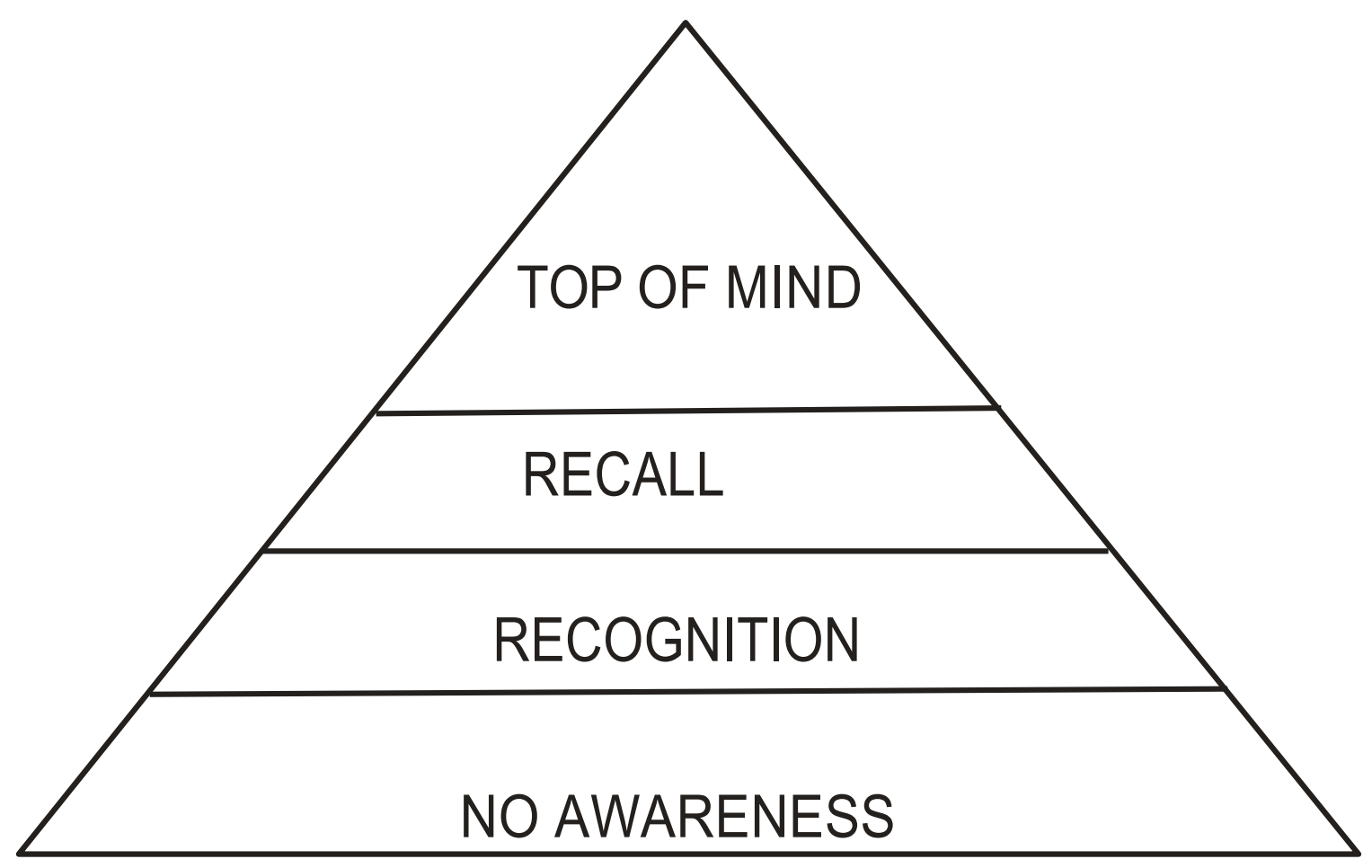

Figure 2 - Levels of brand awareness Source: Aaker, (1998, p. 63)

In marketing studies, brand recognition is verified by presenting interviewees with a set of brands in a determined category and asking them to identify those they have heard about. However, the level of recall is measured by a question involving the spontaneous awareness of the brand within a category of products, without the aid of a list of brand names. By this scheme, the first brand recalled by the interviewee corresponds to the "top of mind" category. (AAKER, 1998). In the case of a new product or service, advertising must create brand recognition because purchase will be unlikely without prior knowledge of the brand by future customers.

According to Carnier (1996), brands can be just as important as the product itself, depending on the case, and the launch of a new product will have greater acceptance and thus promotional advantage if it is linked to an already esteemed brand. According to Gurgel (1995), the brand conveys the concept defined for a perfectly delineated market segment. The development of a brand should involve studies among focus groups made up 
of users representative of the market segment in question.

Carnier (1996) states that in the case of international marketing, branding must take into consideration some technical aspects, since a brand with good acceptance in one national market may not have the same success in other countries, even if the company has developed it to favor its sales in different global markets. An international brand must be short and easy to read, with an agreeable pronunciation in any language. The words, figures and symbols used must be easy to memorize and free of pejorative, obscene or immoral connotations with respect to social and religious customs.

Consumers $^{\text {ee }}$ knowledge of a brand has two basic components: awareness and image of the brand. According to Schultz \& Barnes (2001), brand awareness involves recognition, recall and association of the name, symbol, color, package, advertising and other factors related to a specific brand to which consumers are exposed over time, perceived by sight and sound (Schultz, 2001). A brand"es image is created by associations. Consumers relate the brand to other favorable and unfavorable concepts. The stronger, more favorable or individual these associations are, the lower will be the chances of the brand being copied legitimately by competitors.

Brand loyalty can be created by various factors, but favorable experience of use is the main one and is a necessary prerequisite for its establishment. Other dimensions of the brand that influence customer loyalty are: awareness, the associations promoted and the perceived quality of the brand. In certain cases, according to Aaker (1998), loyalty can derive from only one or a combination of these factors. In other cases, loyalty can arise independently of them, based on a relationship that is not very clear, such as the fast food chain McDonald's, which despite having a low level of perceived quality has a considerable number of loyal customers.

Further according to Aaker (1998), the loyalty demonstrated by consumers to CocaCola, for example, demonstrates the tie that users maintain with the brand, at its highest level. The loyalty pyramid, described in Figure 3, permits identifying five levels of customer brand loyalty. 


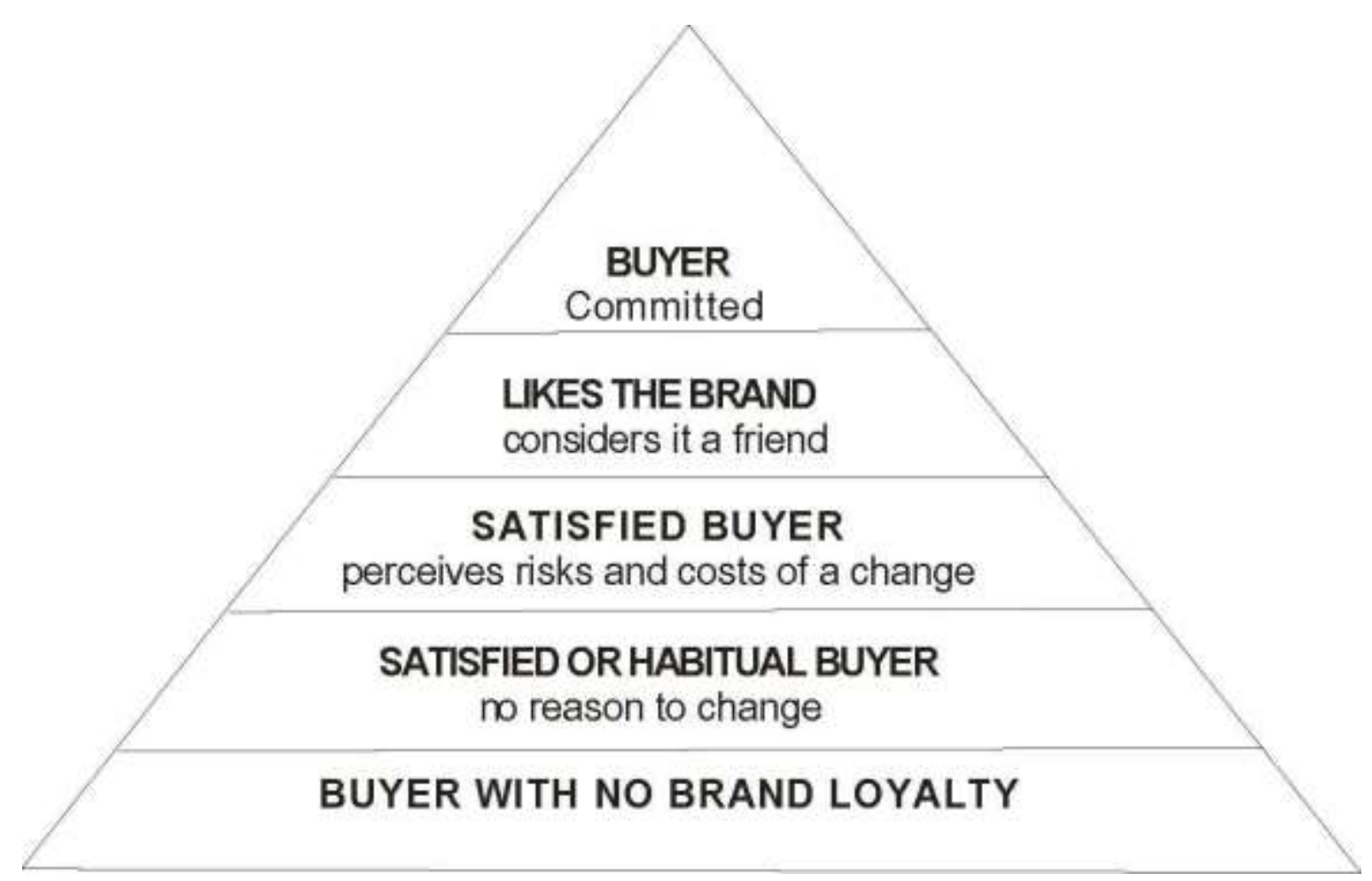

Figure 3 - Brand loyalty pyramid

Source: Aaker (1998, p. 122)

The first level, at the base of the pyramid, corresponds to buyers with no loyalty to the brand. Any product is perceived as adequate and the brand plays an insignificant role in the purchasing decision. The second level covers consumers who are satisfied with the product. They are identified as habitual users, but they are susceptible to appeals from competitors that give them some reason to switch brands. However, there is a certain barrier that must be overcome by competing brands to reach these consumers, because they are often not willing to seek other consumption alternatives. The third level consists of buyers who, besides being satisfied with the brand, perceive some cost in switching.

Therefore, if the benefits offered by the competitor are attractive enough, these consumers will be susceptible to changing to another brand. The fourth level groups buyers who have preference for a brand based on associations with a symbol, previous use experiences or high perceived quality. However, Aaker (1998) stresses the approximation of the consumer with something specific, which does not have empirical support, because people often are not able to explain their reasons for liking a certain brand. Finally, the top level of the pyramid consists of loyal and committed buyers. They feel proud to buy the product and the brand is closely tied in with their personal values, because its functional elements express or translate into what they are. They recommend the brand to other people in their social circles. 


\section{METHODOLOGY}

According to the classification proposed by Gil (1991), this study is predominantly exploratory. From a procedural standpoint, it is basically a field study, through a survey of perceptions with the help of an interview script (Gil, 1991). The data collected were qualitative, which is appropriate for the exploratory research phase (Roesch, 1999).

The interviews were conducted according to a semi-structured, guided script. According to Vergara (2000, p.55), "in a guided interview, the interviewer formulates various points to be explored with the interviewee." The interviews were scheduled in advance by telephone and e-mail, at which time the subject, objective and time necessary were explained. They were conducted in October 2008, generally at the premises of the companies represented by the respondents. We did not require any rigid order of the questions, allowing the respondents to converse at will on the themes proposed. The same questions were posed in all the interviews, so as not to miss any important information. The interviews were recorded on audiotape for greater security of the data gathered.

The unit of study was Brazilian companies that sell their products in both the domestic and international markets, in important agribusiness segments, specifically the pet food and accessories sector (company A), beef sector (company B) and leatherfootwear sector (company C). All three use foreign expressions in building their brands. We conducted semi-structured interviews with executives of these organizations, based on a non-probabilistic sample, chosen by convenience and accessibility, as presented in Chart 2.

\begin{tabular}{|c|c|c|}
\hline COMPANY & COMPANY AREA & RESPONDENT'S TITLE \\
\hline A & Executive Board & Chief Operating Officer \\
\hline B & Quality & Quality Manager \\
\hline C & Marketing & Marketing Analyst \\
\hline
\end{tabular}

Chart 2 - Companies and respondents

Source: Prepared by the authors. 


\section{PRESENTATION AND ANLAYSIS OF THE RESULTS}

Company " $\mathrm{A}$ " is a small Brazilian company that produces pet foods and snacks along with accessories. It has been in business since 2006. Its main product has high quality and natural appeal to Brazilian consumers and is also exported to the European and Canadian markets. The company is considered to be innovative and a possessor of high technology (Company „A“, 2008).

Since its founding in 1972, company "B" has been engaged in the meat packing sector in Brazil and abroad, offering high-quality beef variety meats and prime cuts. It is a mid-sized firm with a packing plant covering $15,462 \mathrm{~m}^{2}$, designed to meet international standards. About $75 \%$ of its sales are to the domestic market and $25 \%$ to international markets (Company “B”, 2008).

Company " $\mathrm{C}$ " is engaged in the leather-footwear sector. It has a plant covering $6,000 \mathrm{~m}^{2}$ and serves the domestic and global markets. Currently exports account for over $30 \%$ of its revenue and its products are exported to 70 countries, including in North America (USA), Europe and Asia, besides Mercosur countries (Argentina, Paraguay and Uruguay) (Company “C”, 2008).

The characteristics of these three firms are summarized in Chart 3 below.

\begin{tabular}{|c|c|c|c|c|c|c|}
\hline \multirow{2}{*}{$\begin{array}{c}\text { Compa } \\
\text { ny }\end{array}$} & \multirow[t]{2}{*}{ Size } & \multirow[t]{2}{*}{ Sector } & \multirow[t]{2}{*}{ Main Products } & \multirow[t]{2}{*}{$\begin{array}{c}\text { Main } \\
\text { Markets }\end{array}$} & \multicolumn{2}{|c|}{ Markets } \\
\hline & & & & & Local & Global \\
\hline A & Small & Pet Foods & $\begin{array}{l}\text { Cat and dog food } \\
\text { and snacks; pet } \\
\text { accessories }\end{array}$ & $\begin{array}{l}\text { Europe; } \\
\text { Canada }\end{array}$ & $90 \%$ & $10 \%$ \\
\hline B & $\begin{array}{l}\text { Mediu } \\
\text { m }\end{array}$ & Beef & Specialty meats & $\begin{array}{l}\text { Africa; } \\
\text { Asia; } \\
\text { Europe }\end{array}$ & $85 \%$ & $15 \%$ \\
\hline $\mathrm{C}$ & $\begin{array}{l}\text { Mediu } \\
\text { m }\end{array}$ & $\begin{array}{l}\text { Leather- } \\
\text { Footwear }\end{array}$ & $\begin{array}{c}\text { Innovative } \\
\text { footwear } \\
\text { (boots/sandals) }\end{array}$ & $\begin{array}{l}\text { USA; Asia; } \\
\text { Europe; } \\
\text { Mercosur }\end{array}$ & $70 \%$ & $30 \%$ \\
\hline
\end{tabular}

Chart 3 - Comparison of the companies surveyed - Source: Prepared by the authors. 


\subsection{Marketing actions utilized in the brand building process}

According the chief operating officer of company "A", the actions are planned and developed by the owners of the company together with an advertising agency, through monthly meetings, at which matters are discussed related to the products, market niches, sales channels and necessary investments. According to the marketing analyst of company "C", the marketing sector analyzes the opportunities, potential markets and budget for marketing actions, along with the marketing mix (price, sales territory, product and distribution). Again, the marketing campaigns are planned with an advertising agency, which develops store materials and other graphic materials for subsequent approval by the company ${ }^{e e}$ s executive board before being used in the target markets. Finally, the quality manager of company "B" stated that the firm "s marketing actions are carried out through an advertising agency with the involvement of the firm ${ }^{\text {ee }}$ marketing sector. Among the points considered are new market opportunities, budget resources available and marketing mix, broken down by domestic and global market. Chart 4 summarizes how the companies are structured in the marketing processes and actions involved in brand building.

\begin{tabular}{|c|c|c|}
\hline Company & Participants & Main Marketing Actions \\
\hline A & $\begin{array}{c}\text { Owners } \\
\text { Advertising Agency }\end{array}$ & $\begin{array}{r}\text { Product positioning; market niches; sales channels; } \\
\text { resources and investments }\end{array}$ \\
\hline B & $\begin{array}{c}\text { Marketing Sector } \\
\text { Advertising Agency }\end{array}$ & $\begin{array}{c}\text { New market opportunities; } \\
\text { and distribution); avaialable budget resources } \\
\text { and marketing mix (price, territory, product }\end{array}$ \\
\hline C & $\begin{array}{c}\text { Marketing Sector } \\
\text { Advertising Agency }\end{array}$ & $\begin{array}{c}\text { Planning of marketing campaigns, opportunities } \\
\text { and potential markets; marketing mix (price, } \\
\text { territory, product and distribution); resources for } \\
\text { marketing actions }\end{array}$ \\
\hline
\end{tabular}

Chart 4 - Comparison of marketing actions

Source: Prepared by the authors.

\subsection{The orientations used in the brand building process}

The choice of names for products or services should involve careful strategic planning to enable the construction of suitable brands. The brand building process can be 
divided into four steps: definition of a brand strategy; determination of themes for creation; generation of names; and final selection (Schultz, 2001).

The brand of company "B", according to its quality manager, was developed based on the opinion of the close family members of the firm "s main owner, together with the participation of an advertising agency. The objective to utilize a brand with American influence arose due to the companyes need to place its products in the global market, with differentiated perceptions by consumers (Company “B”, 2008).

"In my opinion, people with low levels of schooling have a certain difficulty of understanding, but it serves well regarding the perception of our target public" (Quality Manager, 2008).

Firms should develop the objectives to be attained by the brand, to function as essential elements in the choice of the brand name and to orient the company in the development of a strong name that is appropriate for the products and services it intends to place in the market (Schultz, 2001).

According to the marketing analyst of company "C", the construction of the company"s brand was mainly done alone by the company"s main owner, who received the American influences while visiting the West Coast of the United States. In a survey conducted by the company among its customers, the marketing analyst reported that it was accessible to young people, conveying a youthful attitude, modernity and excellent visual impact in the graphic publicity materials and at the sales points of the company, which works with a strategy of publicity campaigns at the global level (Company "C", 2008).

"It wasn"t planned to be global, it was by chance, a question of luck, and people recall the brand; it"s easy to pronounce" (Marketing Analyst, 2008).

To facilitate brand recall, it is important to choose a name that is easy to pronounce and to write, so as to reduce the cognitive effort of consumers. The pronunciation of the name should be taken into careful account, because it is an important factor in word-ofmouth dissemination and should be familiar and accessible to the class in which the product is inserted (Kotler, 1999).

Company "A" hired an advertising agency, which developed its brand by means of presenting a set of names and symbols, and the choice was then made by the company"s owners. According to the chief operating officer, since the brand is associated with the symbol, questions of difficulty of pronouncing a foreign expression were minimized (Company “A”, 2008). 
"People refer verbally to pets for memorizing the brand. The visual impact of the symbol is excellent; anybody who sees it doesn't forget" (Chief Operating Officer, 2008).

The figurative symbol should be quickly identifiable and associated with the company, based on designs that make the type of product the company offers or service it renders very clear, a figure that represents its target public, etc. (Peón, 2001). In this respect, Chart 5 compares the results obtained from the brand building orientations adopted by the companies surveyed.

\begin{tabular}{|c|c|c|c|}
\hline Company & Participants & $\begin{array}{c}\text { Brand Choice } \\
\text { Criteria }\end{array}$ & Brand Identity Elements \\
\hline A & $\begin{array}{c}\text { Company Owners; } \\
\text { Advertising Agency }\end{array}$ & Global products & $\begin{array}{c}\text { Excellent visual impact when } \\
\text { associated with the logo }\end{array}$ \\
\hline B & $\begin{array}{c}\text { Company Owners; } \\
\text { Advertising Agency }\end{array}$ & Global products & $\begin{array}{c}\text { Hard to understand for people } \\
\text { with low schooling levels, but } \\
\text { serves well for the target public } \\
\text { more highly educated people }\end{array}$ \\
\hline C & Company Owners & $\begin{array}{c}\text { Personal } \\
\text { preference }\end{array}$ & $\begin{array}{c}\text { Adequate pronunciation; } \\
\text { excellent visual impact }\end{array}$ \\
\hline
\end{tabular}

Chart 5 - Comparison of the brand building orientations of the companies surveyed Source: Prepared by the authors.

\subsection{Consumers' perception of brands constructed based on foreign influences in the vision of the companies}

In recent decades, new technologies have been rendering longstanding products and services obsolete, and cultural and geographic distances have been shrinking with the advent of the Internet, cheaper jet air travel and satellite communications, among other factors, permitting companies to expand their geographic frontiers.

In this dynamic and global scenario, marketing strategies must be constantly updated in the search for more efficient results by companies of all sizes, which are globalizing at a frantic pace (Kotler, 1998).

Believing in the potential for global growth, company "B" appropriated the use of an American foreignism to serve demand from the external market. According to its quality manager, the brand indicates and conveys to customers attributes related to the 
solidity of the firm, a sophisticated product, trust of demanding consumers and greater credibility of the product, which is sold in the domestic and global markets.

"We intended to create high-quality brands, but using words not before incorporated into the Brazilian vocabulary" (Quality Manager, 2008).

For company "C", the marketing analyst stressed that its brand has become global. The use of expressions in English can be seen since the construction of the brand, in slogans and the description of the line of products. The company ${ }^{\text {ee }}$ marketing campaigns have also become global rather than regional, and are used in more than 70 countries around the world (Company "C", 2008).

"We study the culture of each country so as not to have cultural conflicts, and we use words easy to bring to Brazil, although they are in English" (Marketing Analyst, 2008).

A brand se $^{\text {image attributes are formed by consumers }}$ experience in contact with the brand, word-of-mouth recommendation and personality attributes such as youthful, colorful, sympathetic, smooth - anything that forms a bond between the brand and the product (Tavares, 1998).

The company"es marketing analyst stressed that the brand is well accepted by young people, who attribute to it values such as attitude, spirit of adventure, movement and dynamism, modernity, status, carefree living and fashion (Company "C", 2008).

\begin{abstract}
"We"re going to continue the tendency to use American expressions in our brand and product line, because in Brazil this is accepted. Brazilians to a certain extent think it brings a certain status. We"re a globalized company and are influenced by the global fashion market. Every six months we go to various countries to observe the behavior and record the daily lives of people, the shop windows, launches, collections of the large clothing labels with European and New York inspiration. We go out looking for these aspects, compile our findings and adapt them for the outlines of our products for Brazil" (Marketing Analyst, 2008).
\end{abstract}

For the chief operating officer of company "A", the foreign influence is mainly from American culture, with the expression "pets". The attributes perceived by customers are associated with trust, solidity, more sophisticated products and credibility, providing an opportunity of increase sales in the external market (Company "A", 2008).

\footnotetext{
"The Portuguese language has a very rich vocabulary, but a word like "pets", which covers companion animals of various species, facilitates communication, since the term is short and has broad meaning. The local culture still has a tendency to think foreign things are better. Since we "re entering the international market, we opted for foreign expressions to facilitate pronunciation and memorization. Another motive was that a French name brings sophistication to the brand and is in line with our market niche" (Chief Operating Officer, 2008).
} 
According to Aaker (1998), in the strategic planning of a brand it is important to consider the possible modifications that will have to be made in the brand ee $^{\text {eqmage }}$ to conform to the target market. In analyzing the brand ${ }^{\text {ee }}$ s image, it is important to check the brand ${ }^{\text {ee }}$ s relationship with customers, its personality, the emotional benefits and images associated with it.

Chart 6 compares the results obtained from the interviews regarding the reason for using foreign expressions and the beliefs and attributes perceived by customers, in the opinion of the respondents.

\begin{tabular}{|c|c|c|}
\hline $\begin{array}{c}\text { Compan } \\
\mathbf{y}\end{array}$ & $\begin{array}{c}\text { Reason for using foreign } \\
\text { expressions }\end{array}$ & $\begin{array}{c}\text { Perception/attributes of the } \\
\text { brand }\end{array}$ \\
\hline A & Engagement in global markets & $\begin{array}{c}\text { Solidity; sophistication; trust; } \\
\text { credibility; market scope }\end{array}$ \\
\hline B & To meet the tendencies for \\
globalization & $\begin{array}{c}\text { Product credibility; facilitation of } \\
\text { communication strategies in } \\
\text { foreign markets }\end{array}$ \\
\hline C & $\begin{array}{c}\text { To meet the tendencies for } \\
\text { globalization; engagement in global } \\
\text { markets }\end{array}$ & $\begin{array}{c}\text { Status; power; modernity; market } \\
\text { scope }\end{array}$ \\
\hline
\end{tabular}

Chart 6 - Comparison of the perception of customers in the view of the companies Source: Prepared by the authors.

\subsection{Advantages and disadvantages of using foreign expressions in building brands for} the domestic and global markets

For the quality manager of company "B", the advantages of foreignisms in the Brazilian market are associated with the credibility of its products (beef prime cuts and variety meats) to differentiated retailers, such as Cia Zaffari, Wall Mart and Angeloni, among others. According to him, "the drawback is the difficulty of understanding among the classes of less schooled consumers and in the rejection of people who condemn foreignisms.” In the external market, the foreign expressions help in marketing campaigns 
and new product launches because of easy memorization by customers. He highlighted the disadvantage of using the word "beef" associated with the variety meats line, which has inferior quality than the other beef cuts the company sells (Company "B”, 2008).

According to Tavares (1998), different cultural settings require different approaches. There are a variety of meanings, attitudes, beliefs, rituals, motivations, values and perceptions among different cultures in the context of globalization.

The marketing analyst of company "C" mentioned the use of foreignisms in the domestic market as a competitive advantage due to the acceptance by its customers of expressions of English origin, such as "cool" and "the life style" in its global marketing campaigns.

\begin{abstract}
"Company "C" is a global concern. We use expressions from the English language because the brand is global. Our campaigns are global and we study different cultures of the world to develop slogans, jingles, store materials, Internet pages and catalogs that contain words and expressions from American culture, which are accepted by our customer base in Brazil and other countries to which we export" (Marketing Analyst, 2008).
\end{abstract}

It is very important to use suitable criteria in applying foreign terms, especially those of American origin. It is necessary to follow careful planning in defining a strategy to build brands (Pinho, 1996).

According to the chief operating officer of company " $\mathrm{A}$ ", the use of foreign expression for its products for the Brazilian market has a positive psychological effect on the Brazilian people, who assimilate its products as having better quality than others in the pet market. But a disadvantage is the difficulty of pronouncing a foreign language, which impairs recall of the brand in the national market.

\footnotetext{
"In the international market, we perceive that the public has more culture. In Europe and the United States, for example, we can use our brand without any problem, due the fact that the loan words come from these cultures. The brand"s concepts and meanings are recognized and assimilated more easily by the foreign market. If you go to Europe and say "pets", everybody knows the word has American origin. Here people don"t know the brand"s meaning. I think this is a reality that is connected with culture" (Chief Operating Officer, 2008).

"We bet on this branding strategy, because in the pet market it is very common, especially involving accessories, such as toys, hygiene products, litter box sand, collars and apparel items, to use expressions mainly from English" (Chief Operating Officer, 2008).
}

Cultural factors exercise direct influence on consumers, and marketing experts need to be aware of the role played by the culture, subculture and social class of consumers in trying to foresee the cultural changes that will occur in society, to discover and launch new 
products that satisfy the desires of consumers (Kotler, 1998). Further according to him, marketing professionals that do not adapt to these differences will obtain ineffective results and negative consequences for their organizations.

Chart 7 below compares the results obtained from the interviews.

\begin{tabular}{|c|c|c|c|c|}
\hline \multirow{2}{*}{ Company } & \multicolumn{2}{|c|}{ Domestic Market } & \multicolumn{2}{|c|}{ Global Market } \\
\hline & Advantages & Disadvantages & Advantages & Disadvantages \\
\hline A & $\begin{array}{c}\text { Valorization of } \\
\text { brand with foreign } \\
\text { expressions }\end{array}$ & $\begin{array}{c}\text { Pronunciation of } \\
\text { the brand }\end{array}$ & $\begin{array}{l}\text { Pronunciation } \\
\text { of the brand }\end{array}$ & \\
\hline B & $\begin{array}{c}\text { Credibility; } \\
\text { aggregates value } \\
\text { to the products }\end{array}$ & $\begin{array}{l}\text { Comprehension } \\
\text { by classes with } \\
\text { less schooling; } \\
\text { rejection by } \\
\text { people critical of } \\
\text { foreign }\end{array}$ & $\begin{array}{c}\text { Ease of } \\
\text { dissemination } \\
\text { and } \\
\text { memorization } \\
\text { by customers }\end{array}$ & $\begin{array}{l}\text { Creation of a } \\
\text { frustrated } \\
\text { expectation } \\
\text { (variety meats } \\
\text { line) }\end{array}$ \\
\hline $\mathrm{C}$ & $\begin{array}{l}\text { English terms are } \\
\text { well accepted in } \\
\text { Brazil in the area } \\
\text { of activity }\end{array}$ & & $\begin{array}{c}\text { Acceptance of } \\
\text { English in the } \\
\text { target } \\
\text { countries }\end{array}$ & \\
\hline
\end{tabular}

Chart 7 - Comparison of the advantages and disadvantages of using foreign expressions in building brands Source: Prepared by the authors.

In any event, as seen in the chart, it is necessary to ponder the use of foreignisms, adopting as a balance point the association of marketing strategies and products linked to the conditions and interests of consumer among markets, at the local and global levels.

\section{FINAL CONSIDERATIONS}

From this exploratory survey, it can be seen that the companies studied plan their marketing actions strategically, with the aim of making the marketing mix (price, territory, product and distribution) more effective and efficient. This stance is of basic importance for firms that intend to compete effectively against rivals.

The owners of the companies surveyed were participants in the brand building process. It is very important for this process to be developed in partnership with 
advertising agencies and the company"es marketing experts. The majority of the criteria for choice of brand names were present because the companies sell products in the domestic and global markets. In this respect, firms should correctly evaluate the orientations for building brand identity so as to meet the needs of the markets where their products are sold.

With respect to the perceived attributes and beliefs of consumers about brands constructed relying on foreign expressions, the set of perceived attributes (such as solidity, sophistication, credibility, modernity and status) includes factors that are constantly changing, so they should be measured by marketing experts regularly to adjust the various meanings, beliefs, attitudes, motivations, values and perceptions of consumers about the brand to the different cultural characteristics in the domestic and global markets.

In relation to the advantages and disadvantages of using foreign expressions in building brands in different markets, marketing efforts are very important to reduce ineffective results and negative consequences.

The results of this study suggest that firms, marketing professionals and future entrepreneurs should pay careful attention to the influences of foreignisms in building brands and that marketing efforts need to be developed based on observations and cultural analyses of the target markets.

Finally, executives, managers and other key people in companies, together with marketing experts and agencies, should understand the consequences, limits and advances that foreign expressions generate in our culture, by means of surveys, consultation of the specialized literature and debates with authorities and society in general.

We suggest that other studies can be carried out to expand on the present one by including other agribusiness companies and also firms in other sectors of the economy. It is also important to expand the field of study with quantitative surveys and by testing other theoretical models, which can indicate new aspects of the theme, since new companies and products that adopt foreign expressions in building their brands are constantly emerging, and these firms do not necessarily do so based on concrete information, instead doings so merely to follow the trend or unaware of the impacts this decision can have on the future of the brand and the organization.

\section{REFERENCES}

AAKER, David A. Marcas. Brand Equit: gerenciando o valor da marca. São Paulo: Negócios, 1998. 
ABAURRE, Maria Bernadete Marques; FIAD, Raquel Salek; MAYRINK-SABINSON, Maria Laura Trindade. Cenas de aquisição da escrita: o trabalho do sujeito com o texto. Campinas: Mercado de Letras, 1997-2001.

ASSOCIAÇÃO NACIONAL DE PÓS GRADUAÇÃO E PESQUISA EM ADMINISTRAÇÃO - ANPAD. Disponível em: <http//: www.anpad.org.br>. Acesso em: 15 out. 2008.

AZEVEDO, Eliane. Projeto de lei contra estrangeirismos é puro nacionalismo. São Paulo: JB, 2002.

BAGNO, Marcos. Preconceito linguístico: o que é e como se faz. 5. ed. São Paulo: Loyola, 2000.

CALDAS, Waldenyr. Cultura organizacional e cultura brasileira. São Paulo: Atlas, 1997.

CARNIER, Luiz Roberto. Marketing internacional para brasileiros: o caminho da competitividade em um mercado globalizado. 3ed. São Paulo: Aduaneiras, 1996.

CARVALHO, Nelly. Empréstimos Linguísticos. São Paulo: Ática, 1989.

CATEORA, Philip R.; GRAHAM, John L. Marketing internacional. 10 ed. Rio de Janeiro: LCT, 2001.

CERVO, Amado Luiz. Metodologia científica. 4. ed. São Paulo: Makron, 1996. FONTENELLE, Isleide Arruda. O nome da marca: Mc donald's, fetichismo e cultura descartável. São Paulo: Boitempo, 2002.

FURASTÉ, Pedro Augusto. Normas técnicas para o trabalho científico: explicitação das normas da abnt. 11. ed. Porto Alegre:2002.

GIL, Antonio Carlos. Como elaborar projetos de pesquisa. 4 ed. São Paulo: Atlas, 2002.

GURGEL, Floriano C. A. Administração do produto. São Paulo: Atlas, 1995.

HERRERA LANE, Felipe. O contexto latino-americano e o desafio cultural: homenagem a Andrés Bello. Rio de Janeiro: Fundação Getúlio Vargas, 1983.

HOLANDA, Sérgio Buarque de. História geral da civilização brasileira. 6. ed. Rio de Janeiro: Bertrand Brasil, 1997. 5 v.

JAMESON, Fredric. Marcas do visível. Rio de Janeiro: Graal, 1995.

KELLER, Kevin Lane. Strategic brand management: building, measuring and managing brand equity. New Jersey:Prentice-Hall, 1998.

KOTLER, Philip. Marketing para o século XXI: como criar, conquistar e dominar mercados. 2. ed. São Paulo: Atlas, 1998. 
KOTLER, Philip. Administração de marketing: análise, planejamento, implementação e controle. 5. ed. São Paulo: Atlas, 1998.

LAKATOS, Eva Maria; MARCONI, Marina de Andrade. Metodologia científica. São Paulo. Atlas, 1983.

MACHADO, Ignez De Carvalho. Português uma língua brasileira. 2. ed. São Paulo: Scipione, 1989.

MALHORTA, Naresh K. Pesquisa de marketing: uma orientação aplicada. Porto Alegre: Bookman, 2001.

MCCRACKEN, Grant David. Cultura \& consumo: novas abordagens ao caráter simbólico dos bens e das atividades de consumo. Rio de Janeiro: MAUAD, 2003.

MOTTA, Fernando C. Prestes; CALDAS, Miguel P. (Org.). Cultura organizacional e cultura brasileira. São Paulo. Atlas, 1997.

NICKELS, William G.; WOOD, Marian Burk. Marketing: relacionamentos, qualidade, valor. Rio de Janeiro: LTC, 1999.

PEÓN, Maria Luísa. Sistemas de identidade visual. 2. ed. Rio de Janeiro: 2AB, 2001.

PINHO, José Benedito. O poder das marcas. São Paulo: Summus, 1996.

ROESCH, Sylvia Maria Azevedo. Projetos de estágio e de pesquisa em administração: guia para estágios, trabalhos de conclusão, dissertações e estudos de caso. 2. ed. São Paulo: Atlas, 1999.

SCHMITT, Bernd; SIMONSON, Alex. A estética do marketing: como criar e administrar sua marca, imagem e identidade. São Paulo: Nobel, 2000.

SCHULTZ, Don E.; BARNES, Beth E. Campanhas estratégicas de comunicação de marca. Rio de Janeiro: Qualitymark, 2001.

SERVIÇO DE APOIO ÀS MICRO E PEQUENAS EMPRESAS - SEBRAE. Disponível em:<www.sebrae.com.br>. Acesso em: 10 out. 2008.

STAUB, Augostinus. O empréstimo linguístico: um estudo de caso. Porto Alegre: Acadêmica, 1983.

STRUNCK, Gilberto. Identidade visual: a direção do olhar. Rio de Janeiro: Europa, 1989.

TAVARES, Mauro Calixta. A força da marca: como construir e manter marcas fortes. São Paulo: Harbra, 1998.

VERGARA, Sylvia Constant. Projetos e relatórios de pesquisa em administração. 3. ed. São Paulo: Atlas, 2000. 